\title{
Civil Engineering Megaprojects and Urban Development in Abu-Dhabi, Hong Kong and Sydney
}

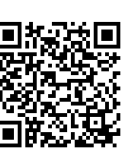

\author{
Gerardo del Cerro Santamaria*, PhD, Dr. Soc. Sci
}

U.S. Fulbright Senior Specialist in Urban Planning, USA

Submission: January 21, 2018; Published: June 19, 2018

*Corresponding author: Gerardo del Cerro Santamaría, U.S. Fulbright Specialist in Urban Planning, New York City, USA Email: gdelcerro@gmail.com

\begin{abstract}
Civil Engineering megaprojects (CEMs) in urban areas epitomize the ambitions of urban elites and their efforts to reposition their cities in a global race for competitiveness and economic development. In the West and other advanced regions of the world, the top-down planning of urban culture and the attempts at engineering cultural capitals has become in the past two decades the policy of choice for municipal and regional power brokers. This paper surveys this trend by focusing on important controversies and disputes generated by the planning, management and governance of civil engineering megaprojects (CEMs) in three globalizing cities (Sydney, Hong Kong and Abu-Dhabi), with an emphasis on the sustainability challenges associated with large-scale redevelopment projects. We use the study of controversies and disputes in UMP development to understand the main challenges for urban governance in cities (usually second and third-tiered cities) seeking to gain global visibility and attract investments and visitors, a strategy adopted by urban elites worldwide in recent times. Our aim is to identify the main participants or sets of participants driving urban policies in such cities as well as the most suitable governance arrangements that could become key for supporting and enabling sustainable urban policies.
\end{abstract}

Keywords: Competitiveness; Economic development; Globalizing; Sustainability; Civil engineering megaprojects

Abbreviations: WHO: World Health Organization's; WKCDA: West Kowloon Cultural District Authority; CEM: Civil Engineering Megaprojects; TCC: Transnational Capitalist Class; TSHD: Trailing Suction Hopper Dredger; HKSAR: Hong Kong Special Administrative Region; PPWK: People's Panel on West Kowloon; CC: Consultative Committee

\section{Introduction}

Civil Engineering megaprojects (CEMs) in urban areas epitomize the ambitions of urban elites and their efforts to reposition their cities in a global race for competitiveness and economic development. In the West and other advanced regions of the world, the top-down planning of urban culture and the attempts at engineering cultural capitals has become in the past two decades the policy of choice for municipal and regional power brokers. This paper surveys this trend by focusing on important controversies and disputes generated by the planning, management and governance of civil engineering megaprojects (CEMs) in three globalizing cities (Sydney, Hong Kong and Abu-Dhabi), with an emphasis on the sustainability challenges associated with large-scale redevelopment projects. We use the study of controversies and disputes in UMP development to understand the main challenges for urban governance in cities (usually second and third-tiered cities) seeking to gain global visibility and attract investments and visitors, a strategy adopted by urban elites worldwide in recent times. Our aim is to identify the main participants or sets of participants driving urban policies in such cities as well as the most suitable governance arrangements that could become key for supporting and enabling sustainable urban policies. We want to be in a position to suggest sensible and useful criteria for sustainable urban governance in policy discourses and practices. Our work builds on recent research about the UMP phenomenon worldwide [1].

Successful cases of redevelopment via civil engineering megaprojects and iconic architecture, such as Bilbao, where the Abandoibarra/Guggenheim megaproject instantly put the city on the map, are not frequent. Policymakers ought to keep in mind that the "visibility" aimed at by CEM construction may not have a significant impact beyond a given locale. CEMs in second or third-tiered cities have limited chances of success outside of their specific locales, and the benefits realized through CEM construction and impacts tend to concentrate around local and regional business interests and the interests of the political elites, rather than benefiting the urban population at large, as Susan Fainstein [2] has shown. An important corollary of this is that the tangible impact of CEMs on the transformation of cities requires consideration of the socio-economic context in which they (both the megaprojects and the cities themselves) develop. With this in 
mind, this chapter seeks to shed light on both the contextual and structural forces framing, enabling and constraining megaprojectbased sustainable urban redevelopment.

The concept of sustainability has evolved in the last few decades into a required aspect of urban and metropolitan-level public action, specifically design and practice of urban and landuse planning. Planning approaches such as New Urbanism, Smart Growth and Sustainable Cities have in turn become the leitmotiv of contemporary planning. As a parallel development, the planning and construction of CEMs in both global and globalizing cities has come to epitomize the ambitions of urban elites and a main priority in the discussions about the chances of increased visibility for local economies and cultures in the global arena. While research on the CEMs phenomenon has grown steadily to the point of becoming an emergent discipline in its own right, little is known about the relationships between CEM sand urban sustainability. In particular, governance arrangements that foster urban sustainability require further research.

Megaprojects are embraced and advocated by urban elites as pro-growth strategies. This view is contested, as they may be less important than developments at the grassroots level that act as catalysts of economic improvement. The study of CEMs helps us understand the dynamics of capitalism and urban development at various spatial and geographical scales. CEMs are also a convenient empirical arrangement to observe how sustainability and sustainable governance work in specific urban settings. While globalization may explain why policy discourses favor CEMs construction, it does not provide an explanation of the specific causal mechanisms through which this form of urban redevelopment seems to be the prime choice for revitalizing cities around the world.

We know that the privatization of planning, usually in the form of new "public-private partnerships", has had an important effect in the specific ways in which megaproject planning, design and construction have taken place. In an entrepreneurial urban context favored by globalizing forces, where public agencies cede control and delegate functions to private institutions and actors, there is a legitimate question from commentators about the meaning of public space. The agencies and administrative procedures that implement planning policy are embedded within the varying organizational structures of states. The structure of new public-private partnerships poses the question of how different the role of contemporary public agencies is from their predecessors.

Researching new forms of collaboration and confrontation between public and private actors and agencies may shed light into the prospects for public space in the city. Further, it would take into account the effects of globalization on privatized control of urban spaces by local and national authorities, and why it is happening in disparate socio-spatial and regional contexts almost simultaneously. Globalization is a contextual, rather than causal, force behind the proliferation of CEMs around the world. It is important to remember that the physical outcomes and impacts of CEMs are usually place-specific, albeit searching for commonalities across various developmental contexts is a legitimate social-scientific task.

\section{Abu-Dhabi: Guggenheim Museum}

\section{Abuses on foreign workers}

Foreign workers in Abu Dhabi comprise 85\% of the workforce, most originating from nearby countries such as Bangladesh, Pakistan, Nepal, India and Sri Lanka. According to a Price Waterhouse Coopers compliance report [3], 86\% of the workers paid illegal recruitment fees to agents, while $92 \%$ said they paid for their own relocation fees including visa, accommodation and travel expenses. These statistics have increased since the previous report, from $75 \%$ and $72 \%$ respectively. Many of these workers are young men who were led to believe they would be working high-paid construction jobs.

Despite their payment, these workers live and work in dire conditions. According to Human Rights Watch [3], some workers were under the impression that they would be working as hotel employees or waiters only to realize they would be working far less lucrative jobs in the construction industry.

The Guggenheim, in conjunction with NYU Abu Dhabi and the Louvre, insisted on the guarantee of worker's rights to prevent discord from board members and donors. Despite this assurance, The Guardian [4] released a 3-month investigative report on the work and living conditions, and found the following:

a) Companies withhold the passports of migrant workers, trapping them in the UAE;

b) Thousands of workers are living in substandard conditions elsewhere in the UAE, in apparent breach of the TDIC's (a developer of major tourism destinations in Abu Dhabi) pledge to house them all in its model Saadiy at accommodation village;

c) Dozens of workers were deported in 2014 for striking over pay and conditions;

d) Mobile-phone video footage of a riot in August shows dozens of men roaming the camp armed with metal spears and planks spiked with nails, with men seen jumping out of windows to avoid the conflict;

e) A worker who claims he lost his leg while building luxury villas has been forced to live on the top floor of a migrant camp for a year. He only received a prosthetic leg last month and has been reliant on the Red Crescent for medical support. His claim for compensation, and request for groundfloor accommodation, have been rejected.

\section{Possibility of downsizing the museum}

The original cost of the Guggenheim was said to be around $€ 800 \mathrm{~m}$ out of the $€ 27 \mathrm{~b}$ budget on the cultural district [5]. 
RaminSalsali, honoree as patron of the arts by the UAE vice president Sheik Mohammed bin Rashid Al Maktoum, said that the project would not stimulate the local economy and cultural development because Abu Dhabi does not need the museum to enhance its reputation. He stated:

"The Guggenheim effect is sexy when you are not on the radar. When you are Bilbao. But Abu Dhabi today - I'm sorry to say, but the Guggenheim should pay Abu Dhabi to be there, not vice versa. Does Abu Dhabi need the Guggenheim still? I don't believe so...The luck is that the delay may provoke a reconsideration of why we should have a Guggenheim of that scale, with that amount of money. Let us downsize it" [6].

\section{Religious and political censorship}

In Abu Dhabi, and specifically in Saadiyat Island (the location of the new Guggenheim), only purely ornamental art is permitted [7], while modern art to be exhibited in the Guggenheim museum is generally regarded as "largely liberal, tolerant and exuberant." [8] This contrast between local culture and modern art would create a clash in society, where "cultural biases threaten to divide the project philosophically while practical differences suggest that the users and providers also disagree about the eminence of economic or aesthetic interests." [8] Verena Formanek, Senior Project Manager of the Guggenheim Abu Dhabi, admitted that the compiling process of contemporary art is difficult because, "[It's] completely different in the process of acquiring the work because we represent the government. This is government money. We want to accelerate slowly, not beginning with the contemporary in the sense that we shock people and no one ever came back here." [6] However, she also noted that the delay in the construction of the museum made time for the government to educate the public and prepare them for the art that is going to be exhibited in the museum. Rita AounAbdo, Saadiyat's Cultural Director, has noted that museums need to develop organically within the local culture, or else their survival is compromised [6].

Apart from religious censorship, there are also worries that there will be political censorship in the Guggenheim after the Arab Spring-a Middle Eastern movement that emerged from Egypt in the hopes of bringing democracy across the continent. Although the political movement largely passed by the UAE [9], it introduced internet restrictions in 2012 on the use of social media to organize protests and imprisoned a large group of Islamists that were charged on plotting a coup in 2013. One example of political censorship include the sacking of Jack Persekian as the Director of Sharjah Biennial in 2011, which planned to display a picture that was offensive to the ruling Sheikh in Sharjah. [10] Wells said that, "No one anticipated that this [Arab Spring] would happen. I think everyone was thinking about religious issues, no one thinking of this powerful political aspect" [6].

In response to worries about censorship, the New York Guggenheim only gave a vague response, stating that, "The Abu Dhabi museum would be international but also reflect and emphasize a specific cultural identity of the Emirates and the wider Arab world" [6].

\section{Adverse effects due to reclamation and breakwaters}

In order to accommodate the Guggenheim Abu Dhabi, along with the Louvre and a Performing Art Centre, new lands and breakwaters are being created [11]. Previous breakwaters in other places are known to stagnate oceanic flow around the area and cause environmental problems. When the flow is stagnated, waste cannot flow out of the area and nutrients cannot flow in, hence further deteriorating the environment along the shore. The turbidity and sedimentation levels along the shores of Saadiyat Island could also increase, which would further harm the aquatic life as insufficient oxygen is dissolved into the water.

Multiple floodings have also occurred during the reclamation projects. According to the environmental impacts report on dredging and reclamation issued by Terra et Aqua, in a settlement pond for the trailing suction hopper dredger (TSHD) has extremely unsatisfactory performance:

"The flow over the pond constantly changed because of differences in reclamation activities and locations. Therefore management of the weir boxes and maintenance of channels and scum booms had to be organised very carefully ... During the course of the project, however, the settlement pond filled up with material. As a result of the constant flow of water over the pond, the material could not be removed and the settling capacity of the pond decreased. Furthermore, the settlement pond was part of the design of the island, and needed to be reclaimed as well. As reclamation progressed, the remaining area for settling decreased and the height of the weir boxes was no longer sufficient to hold enough capacity to ensure tailwater quality... Closer investigation showed that depth of the trenches was still not according to the screen requirements." [11]

Despite the efforts by the TDIC to monitor the water around Saadiy at Island, including turbidity monitoring, tail water sampling and visual observation, there are areas in the project of the construction where monitoring efforts need improvement [11].

\section{Adverse effects on marine life}

Sensitive marine communities, including mangroves, sea grass and coral communities around the area are being adversely affected by dredging activities. For mangrove death to occur, the sedimentation rates of greater than $15 \mathrm{~mm}$ per year just need to smother the aerial roots where gas exchange occurred. Despite the modelling of sediment accumulation indicating little risk of smothering of mangrove roots, mangroves located inside the boundaries of reclamation areas are likely to suffer due to both reclamation and dredging. While mangroves and sea grass are very sensitive to the salinity and acidity of the surrounding water, coral communities are very sensitive to sediment load on surface water. Impervious surfaces, such as roadways, increase the runoff rates 
and carry water mixtures containing pollutants; these waters are eventually discharged into coastal waters. Coral communities are harmed in this process, threatening biodiversity in the area [11].

\section{Hong Kong: West Kowloon Cultural District}

\section{Economic motivation}

Hong Kong's motivation in the West Kowloon Cultural District (WKCD) is viewed as largely focused on economic values, emphasizing tourism. The development of tourism has not been intended to promote culture, but instead to enhance Hong Kong as a 'traditional economic stronghold' as declared by the first Chief Executive of Hong Kong Special Administrative Region (HKSAR) Tung Chee-wah. He stated in his 1998 policy speech, during an economic crisis in Hong Kong, that it was the government's plan to distinguish Hong Kong as 'Asia's world city' and 'Asia's entertainment capital' through megaprojects. After the Asian financial crisis in 1997-99, the "promised" outcomes of megaprojects, as shown in Bilbao, Pittsburgh, Baltimore and other cities attracted Hong Kong leaders [12].

\section{Favoring globalized art industry, excluding local artists}

Major museums such as the Pompidou Center and the Solomon R. Guggenheim Foundation became interested in building a museum in Hong Kong as a part of the WKCD. President Jacques Chirac of France visited Hong Kong in October 2004 to express the Pompidou Center's interest, while Thomas Krens, former Director of the Guggenheim Foundation, had publicly described the initiative as "the most exciting opportunity in the world because of the scale and the location." [13] The WKCD project has hired expertise from world-class art museums and faculties from prestigious higher education institutions as consultants for the project. For example, Lars Nittve, a former Director of the Tate Modern in London and the Moderna Museet in Stockholm, has been appointed Executive Director of the M+ Contemporary Arts Museum [14].

The involvement of Western cultural institutions concerned local artists, as these institutions emphasized global artists' works and thus new arts collectors and revenue for the city at the expense of local artists and cultural groups. Local artists were aware of Hong Kong's status as a sort of "cultural desert" in past decades and aimed to cultivate a unique, locality-based set of initiatives for cultural industries within the city.

Some scholars argued that the development proposals for WKCD fail to enhance the local heritage as the project focuses on "the bundle sale of the development of creative industries." [12] Civic groups such as Project Hong Kong and Citizen Envisioning a Harbour have expressed the locals' concern over a project that will only benefit the real estate developers and the urban elites with a marked preference for Western tastes.

Local artists and civil society in Hong Kong doubt whether the new billion-dollar arts facilities will exhibit meaningful works [15], and others even argue that such facilities are an outdated concept in the $21^{\text {st }}$ century. With these concerns over the necessity of large constructions, there is a voice from civil society to develop 'software' (social institutions that support cultural industries) rather than 'hardware' [16].

While the developments in WKCD were in progress for years, international art fairs such as Art Basel have been strengthening Hong Kong's position as one of the main artistic hubs of Asia, thus overcoming prior marginalization from mainland China. Indirectly, the fairs have been helping the galleries to come in the city and leading to globalization of the art market in Hong Kong. In 2012, a majority of China's 25 percent share of the global art market was based in Hong Kong. The city is now the third-largest art auction center in the world. The perception of Hong Kong and its position as a major art hub has been strengthened as a result of the fair and positive cultural developments throughout the city [14].

\section{Donors and museum directors}

When Lars Nittve, the famed Swedish museum curator, was hired as the Executive Director of $\mathrm{M}+$ (the museum of visual culture in the WKCD), he lobbied UliSigg, a former Swiss diplomat and an important private collector of contemporary Chinese art. The lobbying paid off in 2012, when Mr. Sigg donated 1,463 works worth HK\$1.3b, or about $\$ 165 \mathrm{~m}$ [17]. Sigg chose to donate to the museum in Hong Kong in order to avoid censorship from Chinese government. For art works that can be questioned for their politically charged intentions, Hong Kong is the safer ground in China. Due to this, some artists support the WKCD project in spite of all the controversies and negative effects for the local art community.

\section{Developers and politicians}

Populist politicians in Hong Kong denounced the early versions of the plan as too generous to developers. Tung Cheehwa, the Chief Executive of Hong Kong, initially planned to hand over the entire project to one large developer as expressed in his annual policy address. The plan was decried as a subsidy to the city's wealthiest developer, Li Ka-shing. Even many of Tung's longtime allies among business leaders did not support him in his plan for the WKCD. The plan was revised in October 2005, calling for a lead developer to build half of the residential and commercial real estate on the WKCD Peninsula, while other developers could bid for the rest. The revised rule was objected by the three wealthy developers who submitted proposals under the initial rules [13].

The project was also criticized as property development rather than cultural project due to its connections to the large scale retail industry as well as commercial and residential development interests. The government funding primarily supports shopping, dining and entertainment facilities with expectation of revenues, which is beneficial to the city's wealthy developers. Not surprisingly, raising prices of properties in the neighborhoods could be detected as early as 2010 , and continue today [15]. 


\section{Civil Engineering Research Journal}

Helen Siu and Agnes Ku, Sociology professors at the Hong Kong University of Science and Technology, examined the WKCD project and the Hong Kong's attempt to build a "global city" They explain the relationship among different sectors involved in the project with the local institutional structure and processes, defined by "the cultural policy and institutional framework in colonial times-characterized by non-interventionism and top-down drive under a fragmentary yet centralized structure." Siu and Ku [18] articulate that top-down decision-making structures and the lack of voice from cultural practitioners under globalization has undermined cultural citizenship and civil society in the dominant discourse of globalization [18]. For instance, the People's Panel on West Kowloon (PPWK) was set up by activists in the cultural sector and civic organizations to re-examine the project, seeking cooperation among government, property developers, and civil society. Yes, this Panel never became operative.

A Consultative Committee (CC) and a Core Arts and Cultural Facilities Committee were also established to oversee the provision of cultural infrastructure along with the West Kowloon Cultural District Authority (WKCDA), which oversees the WKCD project. With the WKDCA, the government attempted to distance itself from the awarding of development contracts with the intention 'to be seen as more 'democratic' and engaged with a newly 'liberated' citizenry" [19]. The public outcry forced the government to reconsider and to fix the original project plan. Yet, the trust in government from the locals is substantially lacking in Hong Kong, and the widespread bribery scandals between developers and politicians generated increased criticism toward the project. A corruption trial involving former Chief Secretary Rafael Hui Si-yanin 2014 worsened the public perception of public officials by Hong Kong citizens. Hui allegedly received tens of millions of dollars from Sun Hung Kai Properties (SHKP) as a token of appreciation for his work to favor of SHKP's interests in the West Kowloon project.

Price of the project: need a larger budget: Working poor citizens bear the burden of paying the rising costs of the WKCDA's construction. A total of HK\$950m has been spent on the WKCD project since 2008, and officials have announced plans to invest an additional $\mathrm{HK} \$ 21.6 \mathrm{~b}$ in the project. The price increases are attributed to amendments and plan delays. Global ambition by urban elites has taken precedence over local concerns, which is a criticism that multiple civil society organizations have expressed over the years. Criticism also came from natural allies: the real estate industry questioned the success of the construction and accused the government of damaging their interests with excessive regulation in response to public protests in 2005 [13].

Degradation in surrounding water quality due to reclamation and sewage: The WKCD is constructed by reclamation of the Victoria Harbor. It was initially a trading harbor, and eventually became a tourist spot and an important transit path between the Kowloon Peninsula and Hong Kong Island. The Victoria Harbor provides a natural scenic asset to
Hong Kong, claiming itself to be the "Pearl of the Orient" by the panoramic view seen from airplane windows or skyscrapers in Hong Kong. The Victoria Harbor has attracted 55\% of the tourists coming to Hong Kong in recent years [20]. Reclamation activities became intensified since the 1980s. The amount of land reclaimed from 2000 - 2005 is equivalent to the amount of land reclaimed in the last 100 years, and significant pieces of land reclaimed include 250 hectares of land for container terminals in the port.

The West Kowloon Project has reclaimed 40 hectares of land around the Victoria Harbor [21]. During the construction phase it was expected "construction site runoff, pumped groundwater discharge, drainage diversion, sewage effluent and accidental spillage that contain high levels of suspended solids and chemicals such as oils, solvents and cement-derived materials." [21] The process of dredging is needed to remove unsuitable foundation and replace with large volumes of dredged sand, exacerbating water pollution in Hong Kong. Dredging reduced primary productivity in the sea, affecting the marine ecosystem since they are dependent on plants for sustenance [20]. There is also a loss of sensitive species such as filter-feeding organisms, including scallops, mussels and oysters, which are essential to a vibrant seafood business around Hong Kong. There is also evidence that the Chinese White Dolphins, which is an endangered species unique to Hong Kong, is threatened since dredged materials compromise the well-being of Dolphin Sanctuary neighboring to East Sha Chau Contaminated Mud Pit, where the dredged contaminated mud is disposed of. There are only 85 Chinese Pink Dolphins out of the original 300 , and those that survived were not expected to survive further reclamation [20].

Poor air quality during construction and operational phases: The WKCD is located next to the Western Tunnel Crossing, which connects West Kowloon across the harbor to Hong Kong Island and is one of the busiest locations in Hong Kong. It has one of the worst air qualities with average PM 2.5 concentration around the tunnel crossing at 63 micrograms/cubic meter, which far exceeds the World Health Organization's (WHO) air quality maximum threshold of $25 \mathrm{mg} / \mathrm{m}^{3}$.

During construction, activities such as excavation, stockpiles, the movement of vehicles, concrete batching and the activities of other plants during the loading and unloading operations added onto the already poor air quality around the area [21].

Other major infrastructure construction, such as the Western Harbor Crossing portal, the additional roads and car parks with the WKCD are also affecting the air quality surrounding the area. Since the newly reclaimed land would also accommodate for large number of people during mega events, the resulting pollution, traffic congestion and over-concentration will also aggravate the existing air pollution problem [20].

Landscape impact on the victoria harbor: The project promised to build better landscape in the surrounding area of WKCD, including additions of ornamental plants, a piazza, park 
and avenue through innovative design. [21] (Yet, the effects of greening the space might not be able to compensate for the other landscape impacts. For instance, along with the nearby Kowloon MTR station, Elements Mall International Commercial centers and several enormous apartment buildings are being constructed [22]. Further plans show the construction of skyscrapers in the WKCD, further obstructing the view of the Victoria Harbor [22].

Academic opinions of the project: The WKCD project is a controversial megaproject, which seeks to globalize Hong Kong as an art hub city. Professor Tai-lokLui, as many scholars who criticize the WKCD project, describes the proposal as an example of entrepreneurialism and neo-liberalism:

"Theproposalwasa typicalpackageofurbanentrepreneurialism, with an emphasis on chasing after mega-projects, iconic buildings and media visibility. But it avoided questions concerning the substance of the entire project, consensus from below and the vision of cultural development. Its failure shows that, without addressing these basic questions, city competition by means of developing global architecture, mega-projects and fabricated urban culture is inevitably futile." [12]

Moreover, some scholars point out that the WKCD has already failed to "globalize" Hong Kong, as the project has largely ignored the history, culture and identity of the city. The Brand Hong Kong program of which WKCD is part bears the mission "to provide a greater focus to the international promotion of Hong Kong as 'Asia's world city.'” The marketing strategy of the city's Brand Hong Kong program has, in its preoccupation with these values, marginalized others, according to Stephen Chu. The Donald Tsang administration was keen on developing Hong Kong into a hub of Asian creative industries, but not a base for local creative industries to grow in. As long as the development of creative industries is being framed by the "Brand Hong Kong" concept, vernacular hybrid cultures and spaces cannot surface.

"The overwhelming emphasis on branding Hong Kong has ironically led to the loss of Hong Kong's intrinsic uniqueness: the blending of the global and the local into a hybrid emerging culture which is significantly 'glocal.'”[...] "It attempts to assess the implications of the Brand Hong Kong program's failure in recognizing that the distinguishing characteristic of Hong Kong was its emergent community where genuine cosmopolitanisms found the space to emerge."

\section{Sydney: Olympic Village}

\section{Local impacts compensated by national impact}

The Australian government passed several pieces of legislation that would centralize planning power for the Olympic Games and compromise local government control of developments, including the Olympic Co-ordination Authority Act of 1995; the Sydney Organizing Committee for the Olympic Games Actof [23]; the State Environmental Planning Policy No.38 - Olympic Games and Related Projects; and the Sydney Regional Environmental
Plan No.24 - Homebush Bay Area [24]. As evaluated by Owen, "This legislation consolidated and centralized planning powers with the State Government and with the statutory authorities which were responsible to that Government, particularly the OCA. The legislative changes removed planning power from local governments, vesting consent authority for "all development for the purpose of an Olympic Games project or an OCA project' with the Minister for Urban Affairs and Planning (UA\&P)." [24].

\section{Unsustainable economic gains}

The Sydney Olympic Games were considered by some one of the most economically successful megaprojects in recent decades. According to Haynes, in September 2000 Australia gained its first trade surplus since 1997 with $\$ 677 \mathrm{~m}$, which was a drastic improvement from the $\$ 1.3 \mathrm{~b}$ deficit in August 2000.Conventional opinion had it that Sydney's successful process in the bidding for the Games and its effective marketing plans provide a good example for future host cities. The promotion of a united and stable nation proved beneficial for Australian businesses. The positive exposure to the world opened up numerous trade opportunities in the Asia-Pacific region.

It was forecasted in an economic impact study on the Sydney Olympic Games that indirect tourist expenditure would increase from $\$ 281.6 \mathrm{~m}$ to $\$ 413.4 \mathrm{~m}$ annually after the Games, estimated to approximately 8 to 10 million international tourists per year. However, between 2002 and 2012, Sydney's total number of tourists averaged around 2.5 million. The Australian explained that: "The big mistake that people made - on both state and federal governments - was that they thought the job was over when the flame went out." [25].

The world-class sporting facilities built for the Olympics in the park did not meet financial expectations in the post-Olympic years. The Superdome, which was used to host gymnastic and basketball events during the Olympic Games, has a holding capacity of 21,000 and is the largest indoor stadium in Australia. However, events hosted in post-Olympic years could hardly attract enough people to occupy the whole arena. Within 9 months of the dome's opening, it faced a net loss of $\$ 5 \mathrm{~m}$ annually. Although major sports events like the Sydney Kings national basketball events were hosted at the stadium, such events were infrequent, the average amount of audience was around 4,000 to 5,000 people at each match [26].

\section{Lack of grassroots representation in decision-making processes}

The Olympic Coordination Authority (OCA) was established in 1993 to oversee the transformation of the Home bush Bay into a world-class Olympic Park, and authorities "excluded the Local Council that previously had authority over the site from the regeneration process." [27] As one Auburn Council Officer noted, the Council was not involved "in the planning of ... physical infrastructure at the Park or ... activities/events in 


\section{Civil Engineering Research Journal}

it, which was driven by... a lack of cooperation and interest by ... [OCA officials]. This effectively excluded the local community from any planning decision ... reducing their power within local environmental decisions that may affect them." [27] This, in effect, raised concerns about linking the local community upwards to government officials in order to obtain resources and power to enact changes in their local community. With the central government overpowering the local government, the governance body had a "lack of accountability" to the local community [27].

\section{Pollution at the site of sydney olympic village}

The Sydney Olympic Village was built at Home bush Bay, where previous chemical plants around the area dumped an abundance of waste onto the soil, such as dioxins and chemicals produced by Union Carbide Operations. From 1907 to 1988, this site housed the State Abattoirs and the State Brickworks, which included a quarry for clay and shale to make breaks. In the mid-1980s, when the brickworks and abattoirs were at the end of their operating lives, the area was designated for redevelopment. Consequently, the area was surrounded by chemical plants, fuel terminals, petroleum products, an oil refinery and a prison. Other spaces in the area have been used by the industries for waste dumping [23].

To remedy the situation, the cleaning process would involve either treating or removing the contaminated soil. The Australian and New Zealand Environment and Conservation Council and the National Health and Medical Research Council provided guidelines in dealing with contaminated sites. The ANZECC and NHMC preferred the treatment of soil either on site or off-site, but the strategy adopted for the Home bush Bay only involved the removal of contaminated soil from the site to the worst contaminated area to allow more space for development. This included relocating contaminated soil near the Sports Center to the northern part of the site bounded by Boundary Creek and the Sports Centre Access Roads. The strategy to rehabilitate the area was simply to move the problem elsewhere [23].

\section{Unfulfilled government promises on environmental friendliness}

When Sydney put on the bid for the Olympic Games, Greenpeace Australia's design of a green Olympic Park was chosen as one of the five winners and ultimately led to the publication of guidelines for Olympic Village. Kearins \& Pavlovich claimed that:

"Although an Environmental Advisory Panel was set up as one of six advisory panels to the games organizers, it was later disbanded, and its replacement body apparently lacked sufficient force to become involved at a credible level. In assessing public participation, Albany Consulting Group commented that the Environmental Advisory Panel had been ineffectual 'in drawing into the Olympics preparation process the range of expertise that was available', and was more of a marketing or public relations exercise." [28]
The environmental guidelines set by the environmental committee were also weakened by the OCA in order to "make them easier to use, and stymied the adoption of targets by which success and failure could be judged." [28]

\section{Conclusion}

This chapter focused on important controversies and disputes generated by the planning, design and construction of UMPs in three globalizing cities (Abu-Dhabi, Hong Kong and Sydney), with an emphasis on the sustainability challenges associated with large-scale redevelopment projects. We used the study of controversies and disputes in UMP development to understand the main challenges for urban governance in a group of cities seeking to gain global visibility and thus attract investments and visitors, a strategy adopted by urban elites worldwide in recent times. Our aim was to identify the main participants or sets of participants driving urban policies in such cities as well as the most suitable governance arrangements that can be key for supporting sustainable urban policies. We wanted to be in a position to suggest useful criteria for sustainable urban governance in policy discourses and practices. This conclusion addresses these main objectives [29-32].

Foreign workers in Abu Dhabi are intentionally misled by agents and compelled to work in dire conditions, and religious/ political censorship has caused tension within local the community. Hong Kong's WKCD was planned and promoted as an economic stimulus as opposed to an authentic cultural district reflective of local heritage, at the expense of excluding local artists. Sydney's Olympic Village was planned through the centralization of power for the Australian government, with lower tourist attraction - and revenue generation - than expected [33-39].

\section{Main challenges to urban governance}

The Abu Dhabi case illustrated the exploitation of labour by falsely promising lucrative job opportunities to foreigners for developing its art museum, with minimal consideration of the local culture in which it would be operating. The Hong Kong WKCD case conveyed the deliberate attraction of foreign artists and investors to distinguish the city as an 'art epicenter', and using top-down governance to privilege wealthy property developers by subsidizing their projects. Finally, the Sydney Olympic Village case illustrated the adverse effects of overly centralized planning that can result in removing grassroots representation in decisionmaking and even destruction of the environment [40-44].

Our exploration of the impacts of UMPs on city sustainability strongly suggests that bioeconomy and biodiversity can be vulnerable to the developments. In Abu Dhabi, increasing turbidity and sedimentation levels threatens aquatic life, and reclamation has resulted in floods. The dredging associated with the WKCD in Hong Kong adversely affects the marine ecosystem. The Sydney Olympic Village exacerbated pollution in the area. 
In sum, mediating between private and public sector interests; promoting greater involvement of local and regional governments for projects executed in their communities; engaging citizens more proactively in consultation and direct involvement before, during and after UMP development; enshrining local heritage as a central component of any UMP agreement; and preserving the environment across air, water and land - these are main challenges for sensible urban leaders and policy makers who share the goal of sustainability in urban governance [45-48].

\section{Players in the sustainable governance of UMPs}

The role of civil society: UMPs go beyond the local scale regarding development, implementation and consequences. One of the main driving forces behind their development is the ambitions, often national or global in scope, of local urban elites. Civil society and urban social movements can potentially exert significant grassroots pressure aimed at limiting urban political discourses of exacerbated ambition and grandeur. Specifically, grassroots mobilization can shift the discourse on property development from its current global aims to one of regionalization, welfare and wealth redistribution.

The role of local contexts: The resemblance of most UMPs to conventionalized global city images is suited for some - but clearly not for all - purposes of city marketing. Ultimately, there is always the question of how to distinguish the UMP from other projects and establish city uniqueness. Due to the important role played by local political conditions, replication of successful UMPs elsewhere may necessitate a careful analysis of existing preconditions and even a re-examination of the validity of the strategy when the political-economy climate changes. Recognizing each city's unique identity and cultural context is a prerequisite for the articulation of planning discourses that avoid the serial repetition of redevelopment solutions. Civil society, media and the design profession can play prominent roles here. While swift and a critical adoption of policy formulas from center to periphery has been pervasive around the world in the past few decades of capitalist globalization, political actors at the local level need to keep in mind that each city is a contextual formation that resembles other cities only superficially. This dynamic may represent a structural obstacle for the development of UMPs in globalizing cities and the achievement of their intended objectives [49].

The role of variety and diversity: The star-architect paradox is that they aim to create unique cities and yet we witness the multiplication of similar, aesthetically striking cultural facilities and corporation headquarters worldwide with a homogenizing effect. Often, urban designers are on a quest for vital cities redolent with mixed uses: cities that are daring, imaginative and thrilling. But this is not easy to achieve, and most often neither developers nor planners have any such schemes in mind. Planners tend to create over-sanitized cities that destroy variety and diversity.

The role of public space: Members of the Transnational Capitalist Class (TCC) and their local affiliates can be particularly innovative in creating enclaves that shield them and their families from the worst effects of UMPs, and in propagating consumerism in which new forms of global urbanity rest. UMPs and iconic buildings, according to this view, are a powerful tool in transmitting the consumerist values and practices that sustain capitalist globalization. Contrary to this, it is essential that citizens take back control over public space. Successful cities are authenticated by history and material production; what they don't need is passive observers, spectators, mere consumers [50].

The role of urban design professionals: Design professionals and civil society present a potential for collaboration for urban sustainability. Urban design policy is not usually a basis for radical change; nevertheless, the principal responsibility of urban designers and planners is to create, reinforce and civilize the public realm. Often, intelligent and iconic urban design is a contradiction in terms: successful urban design is a background utility, not a series of spectacular buildings or projects [51,52].

Explorations into the conditions for sustainable urban governance in UMPs help us to critically evaluate the urban megaproject phenomenon and contribute to an understanding of the mutual relationships between globalization, urban development and sustainability. More specifically, such research contributes to an understanding of the complex local circumstances that impact the actual - oftentimes unintended - outcomes of UMPs compared to their projected ones. Sustainability challenges in the urban realm will likely be on the rise in coming decades, as globalization continues unabated and consumerism intensifies and expands to new countries and regions. Researchers will need to develop new conceptual tools and analytical approaches to further understand megaproject-based redevelopments and critically assess their discontents.

\section{References}

1. del Cerro Santamaria G (2013) Urban Megaprojects. A Worldwide View. Emerald, London, UK.

2. Fainstein S (2008) Megaprojects in New York, London and Amsterdam. International Journal of Urban and Regional Research 32(4): 768-785.

3. Mauk B (2014) Abu Dhabi's High Cost of Culture. The New Yorker.

4. Batty D (2015) Migrants building UAE cultural hub 'working in prison conditions', The Guardian.

5. Shadid A (2012) An Ambitious Arab Capital Reaffirms Its Grand Cultural Vision. The New York Times.

6. Batty D (2012) Guggenheim delay raises big question: Is Abu Dhabi ready for modern art? The Guardian.

7. Spiegel online international (2008) Krens' Museum for Global Contemporary Art: Guggenheim Abu Dhabi Will Be 'Pharaonic'. Speigel online.

8. Skluzacek C (2010) Universality and its Discontents: The Louvre and Guggenheim Abu Dhabi as a Case Study in the Future of Museums. 1-72.

9. Dhabi A (2011) Why the Arab Spring Never Came to the UAE. Times.

10. Mcclellan A (2012) Museum Expansion in the Twenty-First Century: Abu Dhabi. Journal of Curatorial Studies Journal of Curatorial Studies 1(3): 271-293. 


\section{Civil Engineering Research Journal}

11. Taelman E (2009) Saadiyat Island Tourist Develoment Project: Dredging and Reclamation Works in an Ecologically Sensitive Area Terra et Aqua 116: 3-11.

12. Lui P (2008) Privatizing the Hong Kong Special Administrative Region Government: Revisiting the Case of The Link REIT from a Policy Network Perspective. Presented at The International Conference on Promoting City Competitiveness, October 24, 2008 at Chung Hua University, Hsin Chu City, Taiwan.

13. Bradsher K (2006) Hong Kong Halts Plans for Arts Center. The New York Times.

14. Chen X (2013) Hong Kong Finds Its Footing in Art World. The New York Times.

15. Lau J (2011) A Bid for Culture in a City of Commerce. The New York Times.

16. Wong, Wendy Siuyi (2004) Design Identity of Hong Kong: Colonization, de-colonization, and re-colonization. In European Academy of Design. University of the Arts, Bremen, Germany.

17. Lau J (2014) Bringing Flagship of Contemporary Art to Hong Kong. The New York Times.

18. Siu Helen, Agnes Ku (2008) Hong Kong Mobile: Making a Global Population. Hong. Kong: Hong Kong University Press.

19. Raco M, Gilliam K (2012) Geographies of Abstraction, Urban Entrepreneurialism, and the Production of New Cultural Spaces: The West Kowloon Cultural District, Hong Kong, Environment and Planning 44(6): 1425-1442.

20. Chan Y (2000) Reclamation and Pollution in Hong Kong with Special Reference to Victoria Harbour. The HKU Scholars Hub. Stable.

21. WKCDA (2013) Annual Report.

22. Dewolf C (2011) The future of Hong Kong's harborfront. CNN.

23. Beder Sharon (1993) Sydneys Toxic Green Olympics. Current Affairs Bulletin 70(6): 12-18.

24. Owen Kristy Ann (2001) The Local Impacts of the Sydney 2000 Olympic Games: Processes and Politics of Venue Preparation. Sydney, Australia: Centre for Olympic Studies.

25. The Australian (2010), August 28, Sydney's squandering of Olympic spoils leaves tourism to count the cost.

26. Searle G (2002) Uncertain legacy: Sydney's Olympic stadiums European Planning Studies 10(7): 844- 860.

27. Prior Jason, Giogio Tavano Blessi (2012) Social Capital, Local Communities and Culture-led Urban Regeneration Processes: The Sydney Olympic Park Experience. Cosmopolitan Civil Societies: An Interdisciplinary Journal 4(3): 78-96.

28. Kearins, Kate, Kathryn Pavlovich (2002) The Role of Stakeholders in Sydney's Green Games. Corporate Social Responsibility and Environmental Management 9(3): 157-169.

29. Arrighi G (1997) Globalization, State Sovereignty and the Endless Accumulation of Capital.

30. Batty D (2013) Conditions for Abu Dhabi's migrant workers 'shame the west'. The Guardian.
31. Batty D (2013) In Abu Dhabi, they call it Happiness Island. But for the migrant workers, it is a place of misery. The Guardian.

32. (2015) Breakwater Facts (n.d.).

33. Brenner Neil, Nikolas Theodore (2002) Spaces of Neoliberalism Urban restructuring in North America and Western Europe. Malden, Mass: Blackwell.

34. Brenner Neil (1998) Global cities, glocal states: global city formation and state territorial restructuring in contemporary Europe. Review of International Political Economy 5(1): 1-37.

35. Castells Manuel (1983) The city and the grassroots: a cross-cultural theory of urban social movements. Berkeley: University of California Press.

36. Caldeira, Teresa Pires do Rio (2000) City of Walls: Crime, segregation and citizenship in São Paulo. Berkeley: University of California Press 24(2): 183-184

37. Yiu-wai CY (2010), Brand Hong Kong: Asia's World City as Method? Visual Anthropology Volume 24(1-2): 46-58.

38. Davis Mike (1991) The City of Quartz: excavating the future in Los Angeles. New York: Vintage Books.

39. del Cerro Santamaria G (2007) Bilbao. Basque Pathways to Globalization. London: Elsevier.

40. Frawley, Stephen (2013) Organising Sport at the Olympic Games: The Case of Sydney 2000. The International Journal of the History of Sport 30(5): 527-44.

41. Friedmann J (2005) Globalization and the Emerging Culture of Planning. Revised version of a paper originally prepared for UN Habitat 64: 183-234.

42. Frug GE (1999) City making: Building communities without building walls. Princeton, NJ: Princeton University Press.

43. Hacking Ian (2003) Risk and Dirt. In, Richard Ericson and Aaron Doyle. Risk and Morality. University of Toronto Press: Toronto.

44. Harvey David (2005) A brief history of Neoliberalism. Oxford: Oxford University Press.

45. Hirst P, Thompson G (1996) Globalization in Question, Cambridge: Polity

46. Judd Dennis (2003) The Infrastructure of Play: Building the Tourist City. Armonk, NY: ME. Sharpe.

47. Dennis J, Fainstein S (1999) The Tourist City. New Haven: Yale University Press.

48. Korporaal G (2010) Sydney's squandering of Olympic spoils leaves tourism to count the cost. The Australian.

49. Sassen S (2006) Territory, Authority Rights, Princeton, NJ: Princeton University Press.

50. Sorkin, Michael (1992) Variations on a Theme Park: The new American city and the End of Public Space. New York: Hill and Wang.

51. Vogel C (2014) A New Art Capital, Finding Its Own Voice.

52. Wade M (2014) Booming Sydney carries struggling national economy. The Sunday Morning Herald. 
This work is licensed under Creative Commons Attribution 4.0 License DOI: 10.19080/CERJ.2018.05.555666
Your next submission with Juniper Publishers will reach you the below assets

- Quality Editorial service

- Swift Peer Review

- Reprints availability

- E-prints Service

- Manuscript Podcast for convenient understanding

- Global attainment for your research

- Manuscript accessibility in different formats

( Pdf, E-pub, Full Text, Audio)

- Unceasing customer service

Track the below URL for one-step submission https://juniperpublishers.com/online-submission.php 